\title{
105. Transformation of Blood Group Substance by Bacterial Enzyme
}

\author{
By Shoei Iseki and Shinju Masaki \\ Department of Legal Medicine, School of Medicine, \\ Gunma University, Maebashi, Japan \\ (Comm. by T. Furuhata, M.J.A., Oct. 12, 1953)
}

Previously, Iseki and Okada ${ }^{1)}$ discovered that Clostridium tertium produces an enzyme which specifically decomposes group A substance, and then Iseki and Tsunoda ${ }^{2)}$ found that Bacillus fulminans produces an enzyme which specifically decomposes $O$ substance. Further study on the subject led us to the discovery that the enzyme of Clostridium tertium, reacting with group A substance, makes its specificity disappear and instead produces $O$ substance. The result is reported in this paper. Now, what is called $\mathrm{O}$ substance here is an Eisler-Kagaya's ${ }^{3{ }^{3)}}$ heterophile antigen. According to Morgan and Watkins ${ }^{5) 6}$, however, O substance in human saliva is distinguished from that in human blood cells, the former being called $\mathrm{H}$ substance.

\section{Materials and Methods}

1) Blood group specific decomposing enzyme. Clostridium tertium was cultured in cooked meat medium at $37^{\circ} \mathrm{C}$ for 48 hours. The culture liquid was adjusted to $\mathrm{pH} 7.4$ and then centrifuged at 12000 r.p.m. The sterile supernatant was used as the A-decomposing enzyme solution.

The autolysate of Bacillus fulminans was centrifuged in a high speed centrifuge, and to the supernatant was added the same volume of cold acetone. The sediment was dissolved in a neutral phosphate buffer, precipitated at 0.4-0.6 saturation of ammonium sulphate, and the precipitate was again dissolved in a phosphate buffer and dialyzed. This was used as the O-decomposing enzyme solution. If the same volume of methanol was added to the dialysate and the precipitate was dried, it is possible for this to be stored.

2) Blood group substance. (1) Human saliva was heated at $100^{\circ} \mathrm{C}$ for 1 hour in a water bath. (2) To extract a carbohydratelike substance from human saliva, a modification of Witebsky and Klendshoj's ${ }^{7)}$ method was employed. Namely, to the boiled saliva was added 2.5 volumes of absolute alcohol and the precipitate was dissolved in distilled water. After repeating this procedure three 
times, protein was removed from the solution by adding trichloroacetic acid. Then again 2.5 volumes of absolute alcohol was added to it, the precipitate dissolved in distilled water, dialyzed in water for 48 hours, and 10 volumes of acetone and a small amount of sodium chloride added to cause precipitation. The precipitate was dried, and when used, dissolved in physiological saline solution. (3) To extract a carbohydrate-like substance from blood cells, Kossjakow's ${ }^{8)}$ method was used. Namely, to blood cells was added 16 per cent alcohol, shaken for 48 hours, and filtered. The filtrate was heated in a water bath for concentration, and trichloroacetic acid was added to remove protein. After its removal the solution was dialyzed for 48 hours, concentrated further, and absolute alcohol was added to produce precipitation. The precipitate was dissolved in distilled water, and 5 volumes of acetone and a small amount of sodium chloride were added to precipitate the carbohydratelike substance. It was dried, and when used, dissolved in physiological saline solution. (4) To purify a blood group substance from hog stomach linings, it was first treated by Bendich, Kabat, and Bezer's ${ }^{9)}$ method. Namely, the stomach linings were finely subdivided in a meat grinder, washed with alcohol and ether, and dried in vacuo. It was then suspended in a citrate-HCl buffer of $\mathrm{pH} 2.3$ containing crystalline pepsin, and the mixture, preserved with toluene, was incubated with occasional mixing at $37^{\circ} \mathrm{C}$ for 3 days. Then it was adjusted to $\mathrm{pH} 2.3$ with concentrated $\mathrm{HCl}$, and to it was added pepsin and after further incubation for 2 days the aqueous digested substance was separated by centrifugation. The sediment was further digested with the same procedure. To the combined supernatants, clarified by filtration through absorbent cotton, 4 volumes of 95 per cent ethanol were added. The precipitate was washed with alcohol and ether, and dried in vacuo. Next, this dried substance was further purified by the phenol method of Morgan and King ${ }^{10)}$. Namely, $1.0 \mathrm{gm}$ of the dried alcohol precipitate was shaken for 1 day with $10 \mathrm{ml}$ of 90 per cent phenol, and the insoluble portion was removed by centrifugation, suspended in $10 \mathrm{ml}$ of phenol, and again shaken for 1 day. These extracts were centrifuged and the supernatants were filtrated by filter paper. To the clear phenol solution, a mixture, of equal volumes of ethanol and 90 per cent phenol was slowly added dropwise untill the final alcohol concentration reached 10 per cent by volume. To ensure floculation, a small crystal of sodium acetate was added to it, and allowed to stand overnight at room temperature. The precipitate thus produced was sedimented by centrifugation, the sediment redissolved in 90 per cent phenol, and again reprecipitated with alcohol-phenol as above. The pre- 
cipitate was suspended in ethanol and allowed to soak overnight to remove phenol. The white product was washed three times with alcohol and with ether, and dried in vacuo. When used in the experiment, it was dissolved in physiological saline solution.

These carbohydrate-like substances from human saliva and blood cells, and the blood group substance from hog stomach linings were all negative in reaction with sulfosalicylic acid, and strongly positive in Molisch reaction.

3) Antisera. As anti-O agglutinin we used chicken antiserum against $\mathrm{O}$ human blood cells, and as anti- $\mathrm{A}$ and anti- $\mathrm{B}$ agglutinins $\mathrm{B}$ and $\mathrm{A}$ human sera, respectively. As anti-O and anti-A precipitins, chicken antiserum against $O$ human blood cells and rabbit antiserum against A blood cells, respectively.

4) Enzymic action. To the solution of blood group substance was added an equal volume of the decomposing enzyme liquid. In this case, the O-decomposing enzyme was adjusted to $\mathrm{pH}$ 6.5-7.0 and the A-decomposing one to $\mathrm{pH} 7.0-7.4$. They were allowed to act at $37^{\circ} \mathrm{C}$ for 48 hours, and then heated in a water bath at $100^{\circ} \mathrm{C}$ for 5 minutes to destroy the enzymic activities. These solutions were centrifuged and the supernatants were examined for the decomposition of the blood group substances. It was determined by agglutinin absorption test and group specific precipitin test.

\section{Results}

1. When the A-decomposing enzyme was allowed to act on group A human saliva, the ability to absorb anti-A agglutinin was lost, and ability to absorb anti-O agglutinin increased. But the ability to absorb anti-B agglutinin did not appear after enzymic action.

2. The O-decomposing enzyme was allowed to act with the carbohydrate-like substances extracted from group A human saliva, group A human blood cells and group A hog stomach linings or with group A human saliva to destroy $O$ substance, and then the A-decomposing enzyme was allowed to act on them. As presented in Tables I and II, both agglutinin absorption test and group specific precipitin test revealed that all group A substances lost the group specificity and came to have the characteristics of $O$ substance. Subsequently it is known that A-decomposing enzyme isolates the determinant group of group A substance and transforms it into $O$ substance.

The carbohydrate-like substance extracted from group A hog stomach linings was partially hydrolized at $\mathrm{pH} 1.5$, with $2 \mathrm{~N}$ hydro- 
chloric acid and examined for blood group substances after 1,2 and 3 hours. In this case it was observed that the destruction of both $O$ and $A$ substances, with the progress of time, was practically identical.

The mechanism of the chemical nature of this A-decomposing enzyme to blood group substances is now under study.

Table I

Activities of O-decomposing and A-decomposing enzymes to group A substances

(Agglutinin absorption test)

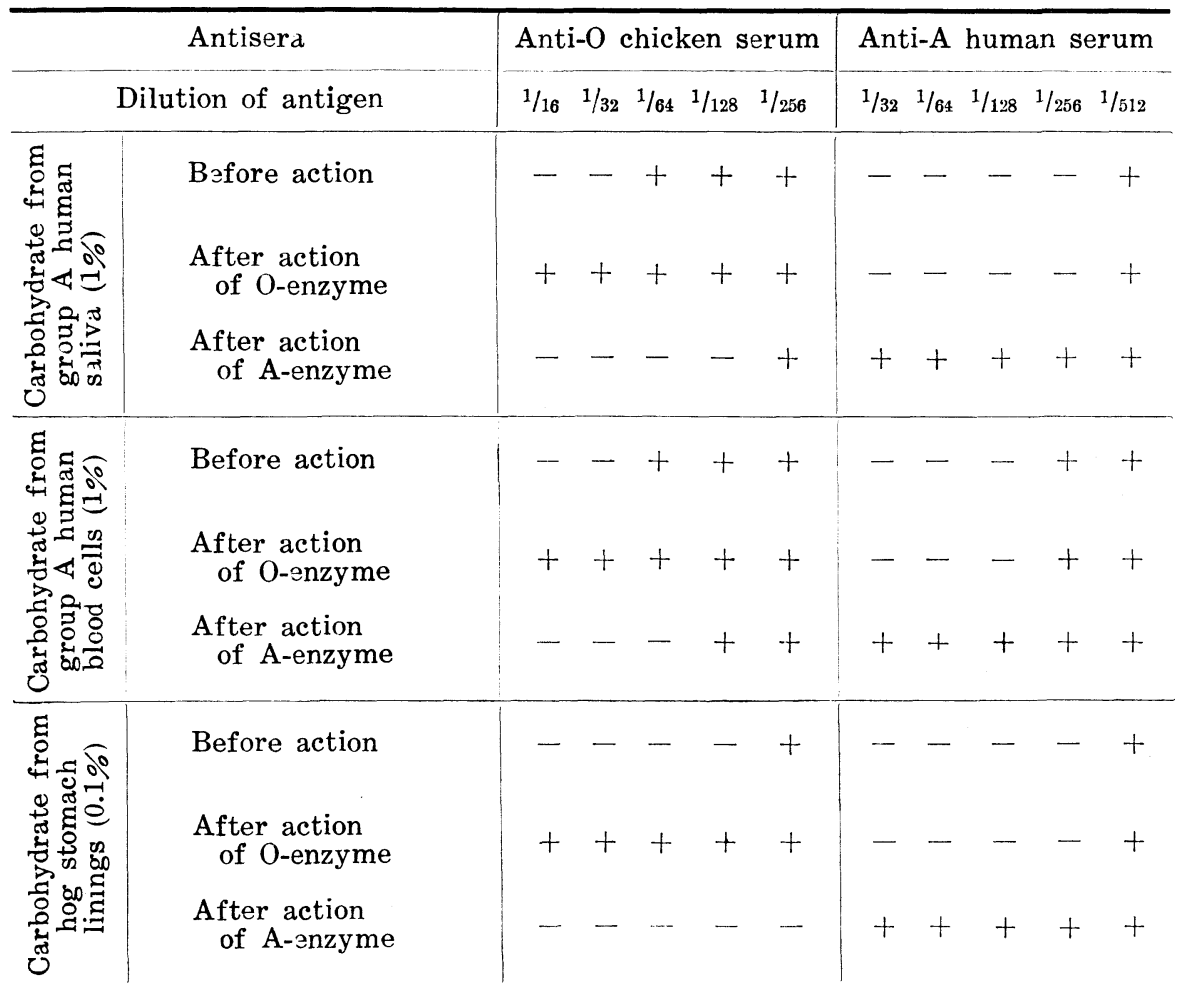

Summary

When the group A substance decomposing enzyme is allowed to act with group A human saliva, the group A substance is decomposed and at the same time $O$ substance is increased.

When the $O$ substance decomposing enzyme is allowed to act with carbohydrate substances from group A human saliva, group A human blood cells and group A hog stomach linings, and after decomposition of $\mathrm{O}$ substance, the A-decomposing enzyme is allowed to act with it, group $A$ specificity disappears and $O$ substance appears. Consequently, it is considered that the A-decomposing 
enzyme isolates the determinant group of group A substance and transforms it into $\mathrm{O}$ substance.

\section{Table II}

Abilities of O-decomposing and A-decomposing enzymes to group A substances

(Precipitin test)

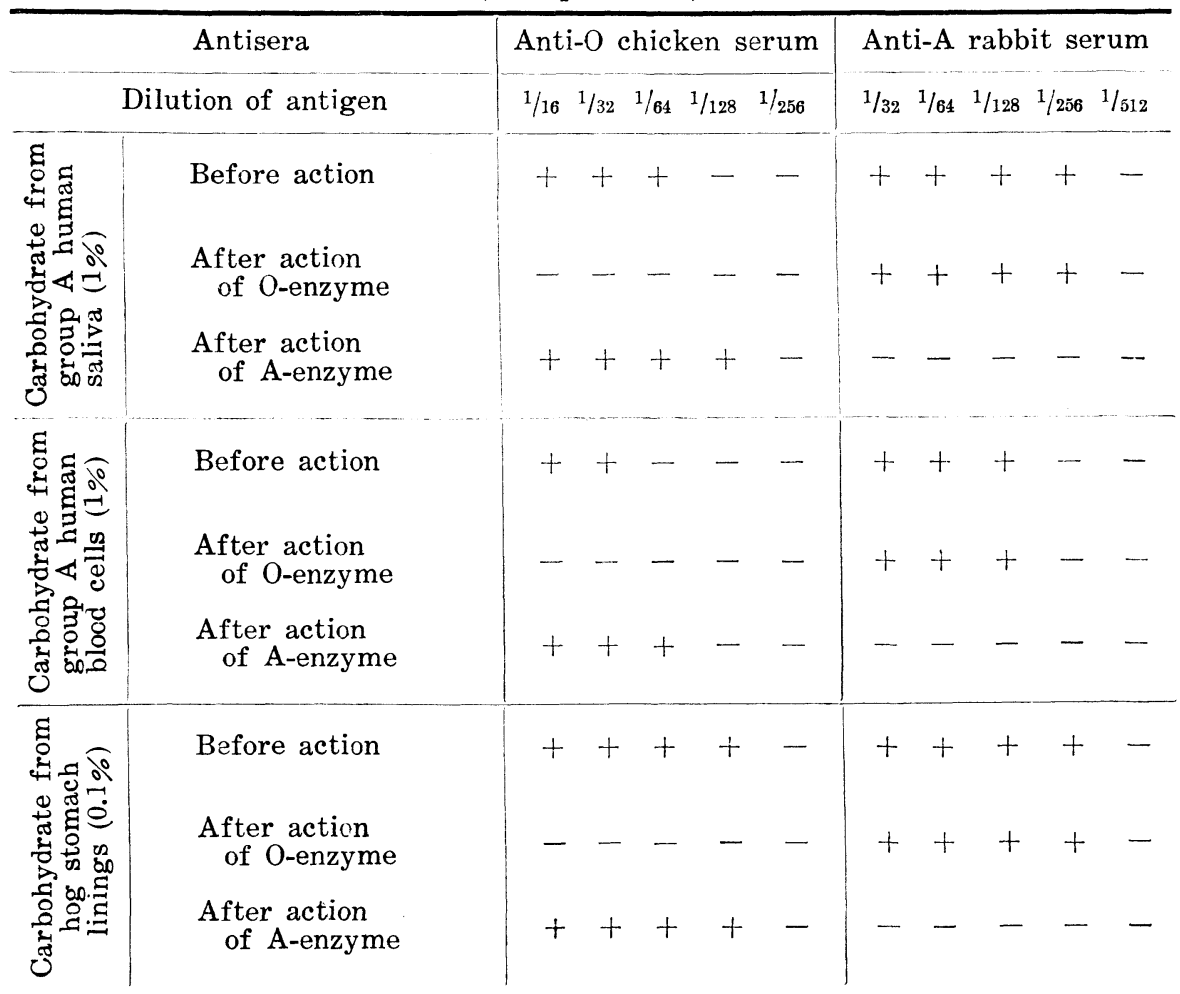

\section{References}

1) Isəki, S. and Okıda, S.: On a specific enzyme which decomposes group A substances. Proc. Japan Acad., 27, 455-458 (1951).

2) Iseki, S. and Tsunoda, S.: On a bacterial enzyme which specifically dec mposes O substance. Proc. Japan Acad., 28, 370-373 (1952).

3) Eisler, M. : Ueber ein gemeinsames Antigen in den Zellen des Menschen und in Shigabazillen. Z. Immunitätsf., 67, 38-48 (1930).

4) Kagaya, Y.: On the human heterophile antigens. Chiba-Igakkai-Zasshi, 15, 44-49 (1937) (in Jap.).

5) Morgan, W.T. J.: The human ABO blood group substances. Experientia, 3, 257-267 (1947).

6) Morgan, W.T. J. and Watkins, W. M.: The detection of a product of the blood group $\mathrm{O}$ gene and the relationship of the sc-called $\mathrm{O}$ substance to the agglutinogens A and B. Brit. J. Exp. Path., 29, 159-173 (1948).

7) Witebsky, E. and Klendshoj, N. C. : The is olation of the blood group specific B substance. J. Exp. Med., 72, 663-667 (1940). 
8) Kossjakow, P. N.: Polysaccharide-Träger der Gruppeneigenschaften des Menschen. Z. Immunitätsf., 99, 221-231 (1941).

9) Bendich, A., Kabat, E. A., and Bezer, A.E.: Immunochemical studies on blood groups. III. Properties of purified blood group A substances from individual hog stomach linings. J. Exp. Med., 83, 485-497 (1946).

10) Morgan, W.T.J. and King, H. K.: Studies in immunochemistry. VII. The isolation from hog gastric mucin of the polysaccharide-amino acid complex possessing blood group A specificity. Biochem. J., 37, 640-651 (1943). 